УДК $630.813 / 812$

\title{
ЭЛЕМЕНТНЫЙ И ГРУППОВОЙ ХИМИЧЕСКИЙ СОСТАВ КОРЫ И ДРЕВЕСИНЫ ОСИНЫ
}

\author{
() И.П. Дейнеко ${ }^{1 *}$, Н.М. Фаустова ${ }^{2}$ \\ ${ }^{1}$ Санкт-Петербургский государственный технологический университет \\ растительных полимеров, ул. Ивана Черных, 4, Санкт-Петербург, 198095 \\ (Россия), e-mail: ipdeineko@mail.ru \\ ${ }^{2}$ Санкт-Петербургский институт фрармации, Партизанская ул., 27, \\ Санкт-Петербург, 195248 (Россия), e-mail: faustova-78@mail.ru
}

\begin{abstract}
Приведены результаты исследования элементного и группового химического состава отдельных частей коры (флоэмы, ритидома) и древесины осины. Кора, в отличие от древесины, имеет повышенное содержание биогенных элементов (N, P), микро- и макроэлементов, а также обогащена экстрактивными веществами, основная масса которых (более $45 \%$ ) извлекается этанолом и $1 \% \mathrm{NaOH}$. Количество веществ, извлекаемых из древесины растворителями (чуть более 5\%), существенно ниже, чем в случае коры. Однако в щелочной раствор из древесины переходит более значительная доля веществ (порядка 15\%). Наружная часть коры по сравнению с флоэмой имеет более высокое содержание углерода, но меньшее содержание азот- и, особенно, фосфорсодержащих соединений. Азотсодержащие соединения в коре представлены преимущественно структурными компонентами, а фосфорсодержащие соединения - фосфолипидами и нуклеотидами. Концентрация макроэлементов во флоэме примерно в два раза выше, чем в ритидоме, и превышает 50 мкмоль/г. В наибольшем количестве в коре присутствуют магний, калий и кальций, причем количество последнего составляет более половины от суммы неорганических элементов. Основными представителями микроэлементов $(1-5$ мкмоль/г) являются цинк, железо, марганец, концентрация остальных (бор, медь, кобальт, молибден и др.) очень мала (менее 1 мкмоль/г). Содержание целлюлозы во флоэме и ритидоме примерно одинаково и более чем в два раза ниже, чем в древесине. Лигнин в максимальной степени накапливается в наружной части коры, где его концентрация превышает 20\%. Для древесины характерно повышенное содержание кислоторастворимого лигнина, массовая доля которого превышает $25 \%$ от суммарного содержания (18\%) этого биополимера.
\end{abstract}

Ключевые слова: осина, кора, флоэма, ритидом, древесина, элементный состав, химический состав, экстрактивные вещества, целлюлоза, лигнин.

\section{Введение}

Кора является одной из важнейших частей дерева, поскольку выполняет разнообразные, необходимые для поддержания жизни всего растения, функции $[1,2]:$ защитную, запасающую, проводящую и опорную.

Несмотря на многочисленные исследования, уровень знаний о свойствах и химическом составе древесной коры невысок, что объясняется сложностью структурной организации этой части дерева, а также влиянием на ее химический состав различных факторов [3, 4]. Химический состав коры, в отличие от древесины, характеризуется значительной межвидовой и внутривидовой изменчивостью. Кроме этого, существенные отличия наблюдаются в анатомическом строении и химическом составе внешней (ритидом, корка) и внутренней (флоэма, луб) частей коры [5].

Одной из широко распространенных и используемых в России лиственных пород деревьев является осина [6]. Кора осины содержит значительные количества соединений, проявляющих высокую биологическую активность $[7,8]$, что обосновывает работы по созданию на основе ее экстрактов лечебных препаратов $[7,9,10]$. Однако знания о химическом составе коры осины, накопленные к настоящему времени, являются

Дейнеко Иван Павлович - профессор, доктор химических наук, e-mail: ipdeineko@mail.ru

Фаустова Наталья Михайловна - научный сотрудник, кандидат химических наук, e-mail: faustova-78@mail.ru неполными [4]. В то же самое время углубление наших знаний о химическом составе и свойствах коры и ее компонентов необходимо для создания процессов рациональной переработки коры.

\footnotetext{
* Автор, с которым следует вести переписку.
} 
В данной работе представлены результаты исследования элементного состава и особенностей группового химического состава отдельных частей коры и древесины осины.

\section{Экспериментальная часть}

Объекты для исследований были отобраны от стволов двух деревьев осины зеленокорой (Populus tremula L.), заготовленных летом в Ленинградской области. Образцы были выпилены в виде шайб (на расстоянии 0,5 м от поверхности почвы) толщиной примерно 0,2 м. Образец 1 был взят у дерева, произраставшего во Всеволожском лесхозе, тип леса - черничник-приручейник, а образец 2 - у дерева, заготовленного на территории Кавголовского лесопарка, тип леса - черничник влажный. Использованные для исследования деревья не имели видимых следов повреждения сердцевинной гнилью. После окорки и разделения коры на внутренний и наружный слои образцы высушивали на воздухе и определяли массовое соотношение отдельных частей ствола. Для химического анализа использовали измельченный материал - фракцию «менее 0,5 мм».

Анализ на содержание углерода и водорода в образцах был выполнен на C,H,N-анализаторе фирмы «Hewlett-Packard» (США), модель 185. Содержание азота было определено с использованием метода Къельдаля $[11,12]$, фосфора - фотоколориметрическим методом на концентрационном фотоколориметре КФК 2МП ( $\lambda=750$ нм) [13] после сжигания образца в смеси: $\mathrm{H}_{2} \mathrm{SO}_{4}$ (конц.) + 60\%-ная $\mathrm{HClO}_{4}+\mathrm{CuSO}_{4}[13]$. Содержание кислорода рассчитывали по формуле: $\mathrm{O}=100-(\mathrm{C}+\mathrm{H}+\mathrm{N}+\mathrm{P})$.

Групповой химический состав образцов был исследован по схеме, представленной на рисунке 1.

Содержание эфиро- и спирторастворимых веществ определено экстрагированием в аппарате Сокслета [15]. В качестве растворителей использовали петролейный эфир $\left(\mathrm{t}_{\text {кип }}=40-70{ }^{\circ} \mathrm{C}\right)$ и $94 \%$ этанол. Анализ на содержание водорастворимых и щелочерастворимых веществ выполнен по стандартным методикам [15]. После каждой стадии экстрагирования в остатке определяли содержание азота и фосфора [12, 14]. Содержание лигнина в образцах находили после их экстрагирования раствором $1 \% \mathrm{NaOH}$ сернокислотным методом в модификации Комарова с определением кислоторастворимого лигнина УФспектрофотометрическим методом ( $\lambda=280$ нм) [15]. Анализ на содержание целлюлозы был выполнен азотно-спиртовым методом [15].

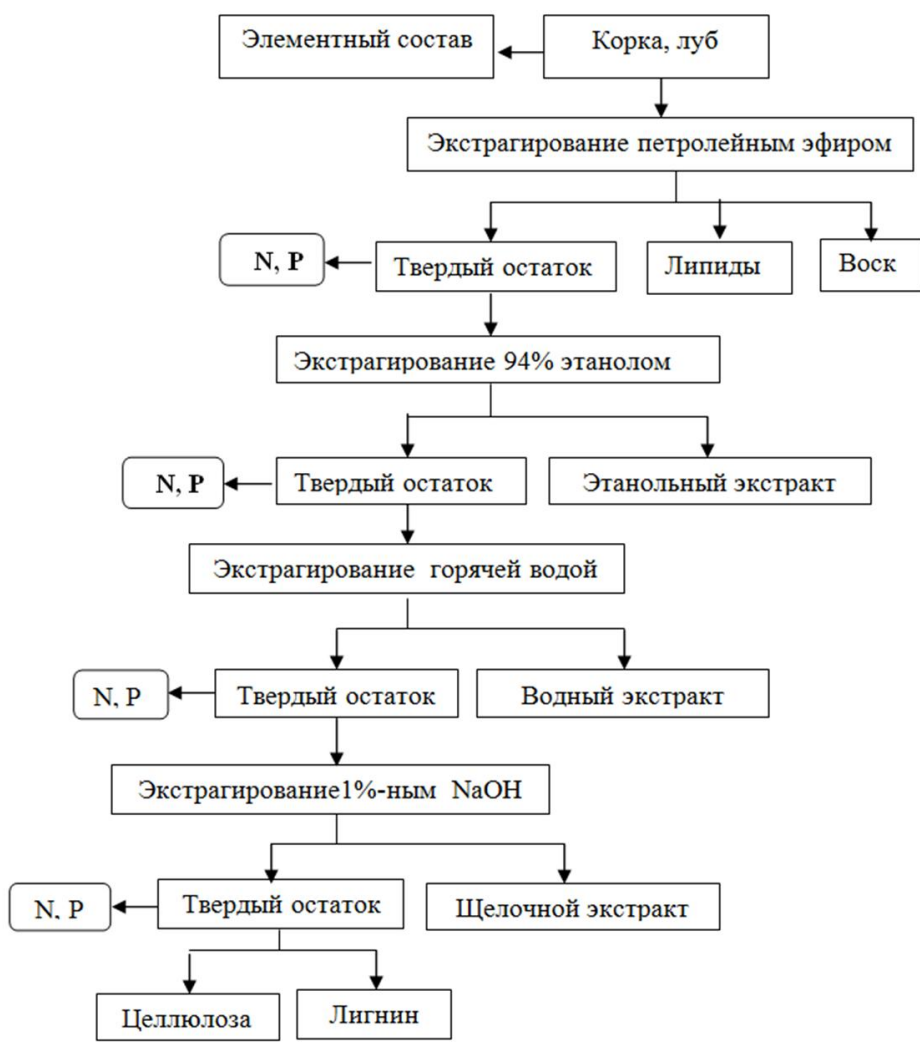

Рис. 1. Схема анализа корки, луба и древесины осины
Анализ неорганических макрои микроэлементов осуществляли методом атомно-эмиссионной спектрометрии с индукционной аргоновой плазмой на атомно-эмиссионном спектрометре ICAP 61E TRACE в Центре исследования качества воды ГУП «Водоканал», СанктПетербург. Подготовку пробы выполняли следующим образом.

Навеску образца массой 1,0 г, взвешенной с точностью до 0,0001 г, помещали в термостойкую колбу объемом 100 мл, заливали 20 мл концентрированной азотной кислоты, закрывали колбу часовым стеклом и оставляли на ночь. Затем колбу помещали на электрическую плитку и после выдерживания в течение часа при слабом нагреве упаривали пробу до половины объема. К полученному раствору осторожно приливали 2 мл $33 \%$ пероксида водорода и упаривали до состояния «влажных солей». После охлаждения к смеси добавляли 2 мл $\mathrm{HNO}_{3}$ (конц.), 20 мл дистиллированной воды 
и «выщелачивали» соли на электрической плитке. Далее раствор переносили в мерную колбу объемом 100 мл и доводили до метки дистиллированной водой. Для градуировочных растворов использовали стандартные образцы водных растворов соединений элементов.

\section{Обсуждение результатов}

Результаты исследования показали, что содержание коры в нижней части ствола спелого дерева весьма значительно и превышает 13\%. Причем в образце 1 доля коры заметно выше, чем в образце 2, что можно объяснить большим возрастом дерева, от которого был отобран образец 1.

Найденное соотношение внутренней и внешней частей коры в образцах показывает, что массовая доля корки в коре исследованных образцов заметно превышает массовую долю луба. Как и в случае всей коры, доля корки в образце более старого дерева существенно выше, чем в случае образца 2. Поскольку наружная часть коры представляет собой комплекс тканей, включающих пер-

Таблица 1. Массовое соотношение корки и луба, \%

\begin{tabular}{l|c|c}
\hline \multicolumn{1}{c|}{ Показатель } & Образец 1 & Образец 2 \\
\hline Число годовых колец & 58 & 52 \\
Массовая доля коры & 16,9 & 13,3 \\
Массовая доля корки & 10,4 / 61,4 & $7,7 / 57,8$ \\
Массовая доля луба & $6,5 / 38,6$ & $5,6 / 42,2$ \\
\hline
\end{tabular}

Примечание: цифра перед чертой - массовая доля корки и луба по отношению к массе ствола, цифра после черты - массовая доля корки и луба по отношению к коре вичную кору, фрагменты перидермы и отмершие ткани луба [16], повышение массовой доли корки в коре очевидно связано с большим вкладом в состав ритидома отмерших клеток флоэмы в дереве с большим числом годовых колец.

Изучение содержания элементов-органогенов показало существенное отличие в элементном составе отдельных частей коры (табл. 2). Мольное соотношение С : Н : О в корке составляет $1: 1,37: 0,59$, а в лубе $1: 1,47: 0,75$. Относительно высокое содержание углерода, и пониженное содержание кислорода в корке свидетельствует о меньшей, по сравнению с лубом, гидрофильности наружной части коры, что обеспечивает снижение интенсивности испарения воды из клеток флоэмы и камбия. В массовых единицах корка содержит примерно на $6 \%$ больше углерода, чем луб и древесина. Мольное соотношение рассматриваемых элементов в древесине (ксилеме) составляет $1: 1,49: 0,80$ и из этих данных следует, что ксилема имеет наиболее высокое содержание кислорода и проявляет наибольшее сродство к воде. Это способствует функционированию клеток ксилемы в качестве тканей, проводящих восходящий ток водных растворов.

Различие в содержании основных элементов-органогенов обусловлено особенностями химического состава и строения компонентов отдельных частей ствола, что проиллюстрировано данными, приведенными в таблице 3 .

В древесине основными компонентами являются углеводы. Видно, что содержание целлюлозы в древесинном веществе осины примерно в три раза больше, чем в коре. Наружная и внутренняя части коры имеют близкое количество целлюлозы - 14,6 и 16,9\% соответственно. В отличие от луба, корка содержит значительную долю клеточных элементов с высокой степенью лигнификации, и это можно отнести к основной причине повышенного содержания углерода в этой части коры. Содержание лигнина в корке $(22,5 \%)$ заметно превышает его содержание в древесине $(18,8 \%)$. Особенностью лигнина древесины является то, что значительная его часть (25\%) представлена кислоторастворимыми фракциями.

Таблица 2. Элементный состав отдельных частей ствола осины, \%

\begin{tabular}{|c|c|c|c|c|c|c|c|}
\hline \multirow{2}{*}{ Часть ствола } & \multirow{2}{*}{ № образца } & \multicolumn{2}{|c|}{ Углерод } & \multicolumn{2}{|c|}{ Водород } & \multicolumn{2}{|c|}{ Кислород } \\
\hline & & массовые & мольные & массовые & мольные & массовые & мольные \\
\hline \multirow{3}{*}{ Корка } & 1 & $53,5 \pm 0,1$ & 34,4 & $6,04 \pm 0,01$ & 46,3 & 40,0 & 19,3 \\
\hline & 2 & $51,3 \pm 0,2$ & 33,2 & $6,00 \pm 0,01$ & 46,3 & 42,2 & 20,5 \\
\hline & среднее & 52,4 & 33,8 & 6,02 & 46,3 & 41,1 & 19,9 \\
\hline \multirow{3}{*}{ Луб } & 1 & $46,4 \pm 0,1$ & 30,8 & $5,79 \pm 0,05$ & 45,8 & 47,0 & 23,4 \\
\hline & 2 & $47,0 \pm 0,1$ & 31,4 & $5,68 \pm 0,13$ & 45,2 & 46,7 & 23,4 \\
\hline & среднее & 46,7 & 31,1 & 5,74 & 45,5 & 46,9 & 23,4 \\
\hline \multirow{3}{*}{ Древесина } & 1 & $45,1 \pm 0,1$ & 30,2 & $5,64 \pm 0,07$ & 45,0 & 49,1 & 24,7 \\
\hline & 2 & $45,9 \pm 0,2$ & 30,4 & $5,78 \pm 0,05$ & 45,6 & 48,2 & 24,0 \\
\hline & среднее & 45,5 & 30,3 & 5,71 & 45,3 & 48,7 & 24,4 \\
\hline
\end{tabular}


Таблица 3. Групповой химический состав отдельных частей ствола осины, \%

\begin{tabular}{|c|c|c|c|c|c|c|c|c|c|}
\hline \multirow[b]{2}{*}{ Компоненты } & \multicolumn{3}{|c|}{ Древесина } & \multicolumn{3}{|c|}{ Луб } & \multicolumn{3}{|c|}{ Корка } \\
\hline & 1 & 2 & $\begin{array}{l}\text { сред- } \\
\text { нее }\end{array}$ & 1 & 2 & $\begin{array}{l}\text { сред- } \\
\text { нее }\end{array}$ & 1 & 2 & $\begin{array}{l}\text { сред- } \\
\text { нее }\end{array}$ \\
\hline \multicolumn{10}{|c|}{ Вещества, извлекаемые } \\
\hline $\begin{array}{l}\text { - петролейным } \\
\text { эфиром }\end{array}$ & $0,56 \pm 0,02$ & $0,51 \pm 0,01$ & 0,53 & $5,35 \pm 0,01$ & $4,59 \pm 0,06$ & 4,97 & $3,91 \pm 0,07$ & $3,92 \pm 0,07$ & 3,91 \\
\hline - этанолом & $2,94 \pm 0,06$ & $3,21 \pm 0,03$ & 3,07 & $30,8 \pm 0,3$ & $28,7 \pm 0,5$ & 29,8 & $24,5 \pm 0,5$ & $18,0 \pm 0,2$ & 21,3 \\
\hline $\begin{array}{l}\text { - горячей } \\
\text { водой }\end{array}$ & $1,73 \pm 0,02$ & $2,03 \pm 0,02$ & 1,88 & $5,35 \pm 0,01$ & $6,6 \pm 0,4$ & 5,97 & $4,7 \pm 0,1$ & $5,59 \pm 0,02$ & 5,1 \\
\hline$-1 \% \mathrm{NaOH}$ & $15,5 \pm 0,0,3$ & $14,4 \pm 0,0,4$ & 15,0 & $31,2 \pm 0,1$ & $23,9 \pm 0,6$ & 27,6 & $26,1 \pm 0,3$ & $24,5 \pm 0,1$ & 25,3 \\
\hline Целлюлоза & $51,9 \pm 0,2$ & $52,0 \pm 0,1$ & 52,0 & $15,7 \pm 0,1$ & $16,9 \pm 0,3$ & 16,3 & $13,5 \pm 0,4$ & $15,6 \pm 0,3$ & 14,6 \\
\hline $\begin{array}{l}\text { Лигнин, } \\
\text { включая: }\end{array}$ & $18,9 \pm 0,1$ & $18,7 \pm 0,2$ & 18,8 & $7,73 \pm 0,3$ & $10,6 \pm 0,1$ & 9,1 & $20,8 \pm 0,2$ & $24,1 \pm 0,8$ & 22,5 \\
\hline $\begin{array}{l}\text { - лигнин } \\
\text { Классона }\end{array}$ & $14,4 \pm 0,1$ & $13,6 \pm 0,2$ & 14,0 & $6,3 \pm 0,3$ & $8,9 \pm 0,02$ & 7,6 & $19,6 \pm 0,2$ & $22,3 \pm 0,8$ & 21,0 \\
\hline $\begin{array}{c}\text { - кислоторас- } \\
\text { творимый }\end{array}$ & $4,5 \pm 0,1$ & $5,1 \pm 0,1$ & 4,8 & $1,43 \pm 0,04$ & $1,66 \pm 0,04$ & 1,55 & $1,19 \pm 0,01$ & $1,78 \pm 0,02$ & 1,49 \\
\hline
\end{tabular}

Как известно, существенным отличием коры от древесины является высокое содержание в ней веществ, извлекаемых растворителями, - экстрактивных веществ $[1,2]$. Результаты нашего исследования показали (табл. 3), что в образцах осины массовая доля экстрактивных веществ во внутренней части коры, особенно веществ, извлекаемых этанолом, существенно превышает их содержание в наружной части коры. Такое различие объясняется наличием во флоэме живых клеток, в которых протекают необходимые для жизнедеятельности растения биохимические процессы. В результате этих процессов образуются метаболиты с относительно небольшой молекулярной массой [17], растворимые в воде и в органических растворителях.

Важнейшие органические соединения, обеспечивающие функционирование живых клеток, имеют в своем составе атомы азота и фосфора. Как видно из данных, приведенных в таблице 4, наиболее высокое содержание этих биогенных элементов характерно для флоэмы. Содержание азота в ритидоме несколько ниже, чем во флоэме, однако существенно выше, чем в ксилеме. Очевидно, после отмирания клеток покровных тканей и клеток флоэмы в них остается часть не реутилизированных азотсодержащих соединений. То же самое можно отметить и для фосфорсодержащих соединений, мольная доля которых в корке значительно ниже, чем в лубе.

Следует подчеркнуть, что, несмотря на повышенное, по сравнению с ксилемой, содержание азота и фосфора в коре, доля этих элементов в суммарном содержании элементов-органогенов невысока и примерно на три порядка ниже, чем содержание углерода и кислорода. Это говорит о том, что относительная доля азот- и фосфорсодержащих соединений в коре по сравнению с кислородсодержащими органическими соединениями невелика.

Поскольку азот и фосфор входят в состав соединений разнообразной природы, нами было изучено распределение содержания этих элементов в различных группах экстрактивных веществ коры. Результаты анализа образца 2 представлены в таблице 5. На основании полученных данных можно сделать вывод о существенных отличиях в растворимости азот- и фосфорсодержащих соединений, находящихся в разных частях коры.

Таблица 4. Содержание азота и фосфора в отдельных частях ствола осины

\begin{tabular}{|c|c|c|c|c|c|}
\hline \multirow{2}{*}{ Часть ствола } & \multirow{2}{*}{ Образец } & \multicolumn{2}{|c|}{ Азот } & \multicolumn{2}{|c|}{ Фосфор } \\
\hline & & $\mathrm{M} \Gamma / \Gamma$ & мкмоль/Г & $\mathrm{M} \Gamma / \Gamma$ & мкмоль/Г \\
\hline \multirow{3}{*}{ Корка } & 1 & 4,0 & 286 & 0,151 & 4,9 \\
\hline & 2 & 4,9 & 350 & 0,151 & 4,9 \\
\hline & среднее & 4.45 & 318 & 0,151 & 4,9 \\
\hline \multirow{3}{*}{ Луб } & 1 & 6,9 & 493 & 0,69 & 22,3 \\
\hline & 2 & 5,3 & 379 & 0,62 & 20,0 \\
\hline & среднее & 6,0 & 436 & 0,65 & 21,7 \\
\hline \multirow{3}{*}{ Древесина } & 1 & 1,58 & 113 & 0,088 & 2,8 \\
\hline & 2 & 1,5 & 111 & 0,060 & 1,9 \\
\hline & среднее & 1,57 & 112 & 0,074 & 2,5 \\
\hline
\end{tabular}


Таблица 5. Распределение азота и фосфора по стадиям экстракции

\begin{tabular}{|c|c|c|c|c|c|}
\hline \multirow{2}{*}{$\begin{array}{l}\text { Материал после } \\
\text { экстрагирования }\end{array}$} & \multirow{2}{*}{$\begin{array}{c}\text { Выход } \\
\text { остатка, \% }\end{array}$} & \multicolumn{2}{|c|}{$\mathrm{N}$ в остатке } & \multicolumn{2}{|c|}{ Р в остатке } \\
\hline & & $\mathrm{M} \Gamma / \Gamma$ & \% от N исх. сырья & $\mathrm{M} \Gamma / \Gamma$ & \% от Р исх. сырья \\
\hline \multicolumn{6}{|c|}{ Луб } \\
\hline Исходное сырье & 100 & 5,3 & 100 & 0,62 & 100 \\
\hline Петролейным эфиром & 95,1 & 4,3 & 78,6 & 0,55 & 83,6 \\
\hline Этанолом & 66,4 & 5,6 & 71,5 & 0,63 & 67,1 \\
\hline Водой & 59,8 & 5,5 & 63,2 & 0,19 & 18,2 \\
\hline $1 \%$ раствором $\mathrm{NaOH}$ & 35,5 & 4,0 & 27,3 & 0,17 & 9,7 \\
\hline \multicolumn{6}{|c|}{ Корка } \\
\hline Исходное сырье & 100 & 4,9 & 100 & 0,15 & 100 \\
\hline Петролейным эфиром & 96,0 & 4,4 & 86,2 & 0,14 & 89,6 \\
\hline Этанолом & 78,0 & 4,3 & 69,2 & 0,13 & 68,2 \\
\hline Водой & 72,4 & 4,4 & 65,7 & 0,12 & 56,1 \\
\hline $1 \%$ раствором $\mathrm{NaOH}$ & 47,9 & 2,8 & 27,4 & 0,066 & 20,9 \\
\hline
\end{tabular}

Приведенные данные показывают, что при последовательной обработке луба и корки растворителями возрастающей полярности происходит постепенное извлечение азот- и фосфорсодержащих соединений. Однако даже после обработки водным раствором щелочи в проэкстрагированном материале остается заметная доля веществ, в структуру которых входят атомы азота и фосфора.

Более наглядно долю азот- и фосфорсодержащих соединений, экстрагируемых различными растворителями, отражают диаграммы, приведенные на рисунке 2.

Видно, что примерно пятая часть всего находящегося в коре азота и фосфора включена в компоненты луба, извлекаемые петролейным эфиром, т.е. входит в состав фосфолипидов, которые наряду с жирными кислотами и спиртами содержат остатки фосфорной кислоты и азотистые основания [17, 18]. Однако, поскольку мольная доля азота в лубе более чем на порядок превышает мольную долю фосфора, можно заключить, что петролейным эфиром извлекаются и другие азотсодержащие органические вещества.

\section{Азотсодержащие вещества корки}

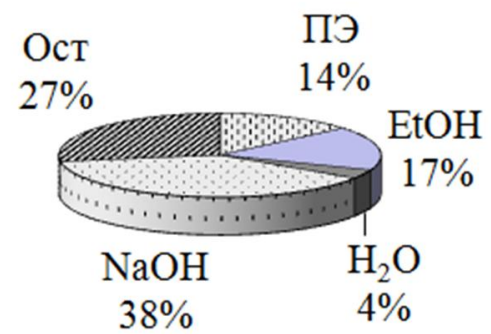

Фосф орсодержащие вещества корки

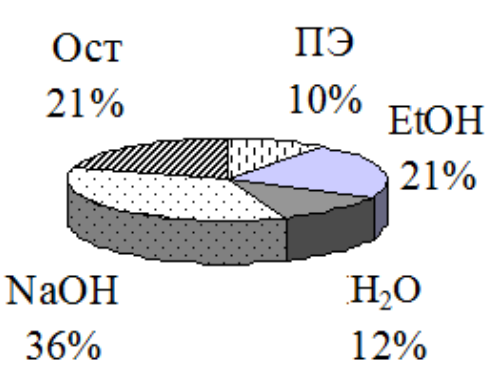

\section{Азотсодержащие вещества луба}

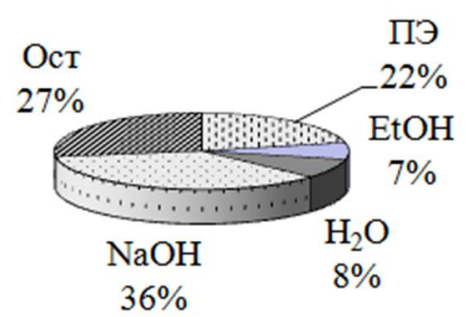

Фосфорсодержащие вещества

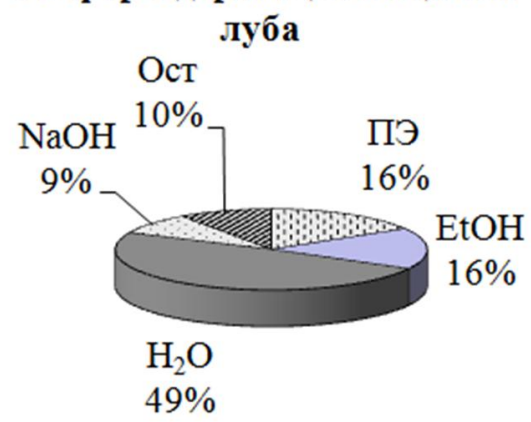

Рис. 2. Массовая доля азота и фосфора в различных группах экстрактивных веществ, \% от общего содержания элемента (ПЭ - вещества, растворимые в петролейном эфире; ЕtОН - вещества, растворимые в этаноле; $\mathrm{H}_{2} \mathrm{O}$ - вещества, растворимые в воде; $\mathrm{NaOH}$ - вещества, растворимые в $1 \%$ растворе $\mathrm{NaOH}$; Ост - вещества в нерастворимом остатке) 
Обращает на себя внимание то, что малополярные липофильные вещества, как луба, так и корки представлены среди экстрактивных веществ в наименьшем количестве (см. табл. 3). Поэтому достаточно высокая доля извлекаемых петролейным эфиром азотсодержащих веществ свидетельствует об их важной роли в функционировании живых клеток. Корка имеет несколько меньшее содержание липидов, чем луб (см. табл. 3), в том числе и азотсодержащих соединений. Однако свойства этой группы веществ, содержащихся в ритидоме, имеют определенные особенности. Примерно половина липидов корки осаждается из раствора петролейного эфира после охлаждения. Липофильные вещества, проявляющие такие свойства, относят к воскам [18], которые, находясь на поверхности клеток покровного слоя, участвуют в регулировании влагообмена древесного растения.

Как в корке, так и в лубе содержится большое количество веществ, извлекаемых этанолом. Основными компонентами этой фракции, как было показано в работе [9], являются фенольные соединения. Что касается азотсодержащих веществ, то массовая доля этих компонентов, содержащаяся в корке, заметно выше, чем в лубе, что можно объяснить присутствием в наружной части коры растворимых в спирте белков (проламинов) [19] и продуктов распада протеинов - олигопептидов. В состав удаляемых из корки и луба веществ входит значительная доля фосфорсодержащих соединений (21 и 17\% соответственно), вероятно, представляющих собой полярные фосфолипиды [20].

По сравнению с компонентами, выделяемыми этанолом, водой из коры извлекается сравнительно небольшая часть соединений, которые можно отнести к низкомолекулярным углеводам [17]. И для корки, и для луба характерно низкое содержание водорастворимых азотсодержащих соединений, представляющих собой, по-видимому, аминокислоты; при этом доля их в лубе выше по сравнению с коркой примерно в 2 раза.

Наибольшая часть соединений, содержащихся в коре, в том числе и соединений азота, сосредоточена в компонентах, извлекаемых водно-щелочным раствором. По-видимому, азотсодержащие соединения, растворимые в щелочной среде, можно отнести к полипептидам, входящим в состав клеточных стенок коры, так называемые структурные белки [17, 21]. Значительная часть азотсодержащих соединений не извлекается из коры при обработке растворителями и щелочным раствором. Вероятнее всего, эти компоненты представляют собой также структурные белки, однако в отличие от растворимых в щелочном растворе полипептидов эти соединения связаны поперечными связями с другими компонентами клеток, формируя с ними сетчатую структуру клеточных оболочек [21].

Таким образом, рассмотренные экспериментальные данные позволяют сделать вывод, что почти две трети от суммарного количества азотсодержащих соединений во внешней и внутренней частях коры входят в состав структурных белков.

В отличие от азота большая доля фосфора флоэмы (около 50\%) входит в состав соединений, растворимых в воде. Повышенное содержание водорастворимых форм фосфора в лубе объясняется присутствием в отдельных клеточных элементах значительного количества сильно полярных фосфорсодержащих соединений, вероятнее всего, нуклеотидов и их производных, обеспечивающих функционирование живых тканей [22].

В корке доля водорастворимых соединений фосфора существенно ниже и составляет только $12 \%$. Наибольшая часть соединений фосфора (36\%) извлекается из корки при обработке раствором щелочи. В лубе же массовая доля этих соединений не достигает и $10 \%$. Однако, поскольку общее содержание фосфорсодержащих соединений в лубе более чем в четыре раза превышает их содержание в корке, количество названных компонентов в наружной и внутренней частях коры сравнимо. Можно предположить, что такие компоненты представляют собой структурные белки, содержащие остатки фосфорных кислот, за счет которых они и имеют высокое сродство к щелочному раствору.

В наружной части коры содержится также значительная доля (21\%) нерастворимых фосфорсодержащих соединений; их массовая доля в ритидоме больше, чем во флоэме, в 2 раза. Можно предположить, что наружная часть коры имеет высокое содержание солей фосфорной кислоты и ее производных, имеющих низкую растворимость в водных средах [23].

Помимо рассмотренных биогенных элементов, для обеспечения физиологических процессов растениям необходимы минеральные вещества, которые поступают в растение из почвы за счет восходящего тока водного раствора осуществляемого проводящими тканями как ксилемы, так и флоэмы [24, 25]. Минеральные питательные вещества для растений имеют очень большое значение. Они могут играть роль 
структурных компонентов растительных тканей, катализаторов различных реакций, регуляторов осмотического давления и проницаемости мембран, а также компонентов буферных систем [26].

Важную роль в функционировании растения играют такие макроэлементы, как калий, кальций и магний. Ионы калия и кальция широко участвуют в механизмах физиологического контроля и в пусковых механизмах, а также совместно с ионами магния необходимы для поддержания структуры клеточных стенок [27]. Приведенные в таблице 6 данные показывают, что все названные элементы присутствуют в коре в значительных количествах. Следует отметить довольно сильные отличия в количественном содержании как макро-, так и микроэлементов в двух взятых для исследования образцах. Это, очевидно, является следствием различий в условиях произрастания этих деревьев и химическом составе почвенных растворов [27]. Наиболее высокое содержание в коре характерно для кальция; мольная доля его в лубе более чем в два раза превышает количество калия и в шесть раз превышает количество магния. По сравнению же с древесиной содержание кальция в корке и лубе в среднем в 14 и 7 раз соответственно больше, чем в ксилеме.

Известно, что соединения кальция стабилизируют мембраны, снижают их проницаемость [29]. Кроме этого, кальций входит в состав пектиновых веществ, а также расходуется на нейтрализацию щавелевой кислоты [25], что объясняет большее содержание этого комплекса в коре, а именно в лубе, по сравнению с древесиной $[5,26]$. В растворимой форме кальций находится преимущественно в молодых частях растения, а нерастворимые карбонаты, фосфаты и оксалаты откладываются в старых частях коры в виде инкрустаций [30, 31].

Содержание ионов калия коррелирует с содержанием азота: богатые белками органы растения содержат обычно много калия [32]. В соответствии с этим количество этого элемента выше в лубе, чем в корке, почти в 3 раза и больше, чем в древесине, в 7 раз. Однако в отличие от коры относительное содержание ионов калия в древесине выше, чем других макроэлементов. Поддерживая водный баланс в клетке, калий способствует приобретению белками определенной конформации, благоприятной для метаболических реакций. Кроме того, будучи господствующим катионом во флоэмном соке и обеспечивая тем самым требуемое осмотическое давление в проводящей системе, калий участвует в активном транспорте ассимилятов к органам запасания. Хорошее снабжение калием снижает интенсивность дыхания растений и повышает содержание углеводов [30].

Распределение магния по частям ствола подобно распределению кальция и калия, что связано с некоторыми общими с кальцием и калием физиологическими функциями этого макроэлемента [26]. По аналогии с калием магний является кофактором многочисленных ферментов. Считается также, что магний стабилизирует структуры рибосом [32].

Не менее важную роль в жизни растения играют и другие элементы, количество которых существенно ниже, чем количество рассмотренных элементов. Поэтому их относят к необходимым микроэлементам [33]. Содержание важнейших микроэлементов в коре и древесине приведено в таблице 7.

В наибольших количествах в отдельных частях ствола присутствуют такие микроэлементы, как ионы железа, марганца и цинка. При этом содержание этих элементов, за исключением цинка, в наружной и во внутренней частях коры сравнимо. Очевидно, что после отмирания живых клеток флоэмы находящиеся там микроэлементы фиксируются структурными компонентами клеток за счет хемосорбционных процессов [24].

Таблица 6. Содержание макроэлементов в отдельных частях ствола осины

\begin{tabular}{|c|c|c|c|c|c|c|c|}
\hline \multirow{2}{*}{$\begin{array}{c}\text { Часть ство- } \\
\text { ла }\end{array}$} & \multirow{2}{*}{ № образца } & \multicolumn{2}{|c|}{ Калий } & \multicolumn{2}{|c|}{ Кальций } & \multicolumn{2}{|c|}{ Магний } \\
\hline & & $\mathrm{M \Gamma} / \Gamma$ & мкмоль/Г & $\mathrm{M \Gamma} / \Gamma$ & мкмоль/Г & $\mathrm{M \Gamma} / \Gamma$ & мкмоль/Г \\
\hline \multirow{3}{*}{ Корка } & 1 & 2,4 & 61,4 & 4,50 & 112 & 0,37 & 15,2 \\
\hline & 2 & 1,7 & 43,4 & 7,10 & 177 & 0,40 & 16,5 \\
\hline & среднее & 2,05 & 52,4 & 5,80 & 140 & 0,39 & 15,9 \\
\hline \multirow{3}{*}{ Луб } & 1 & 4,6 & 118 & 12,0 & 299 & 1,20 & 49,4 \\
\hline & 2 & 5,6 & 143 & 11,5 & 282 & 1,10 & 45,3 \\
\hline & среднее & 5,1 & 131 & 11,7 & 291 & 1,15 & 47,4 \\
\hline \multirow{3}{*}{ Древесина } & 1 & 0,91 & 23,3 & 0,63 & 15,7 & 0,16 & 6,6 \\
\hline & 2 & 0,67 & 17,1 & 0,80 & 20,0 & 0,11 & 4,5 \\
\hline & среднее & 0,79 & 20,2 & 0,79 & 17,9 & 0,14 & 5,6 \\
\hline
\end{tabular}


Таблица 7. Содержание микроэлементов в отдельных частях ствола осины (перед чертой - мг/100 г, за чертой - мкмоль/100 г)

\begin{tabular}{c|c|c|c|c|c|c}
\hline \multirow{2}{*}{ Элемент } & \multicolumn{2}{|c|}{ Корка } & \multicolumn{2}{|c}{ Луб } & \multicolumn{2}{c}{ Древесина } \\
\cline { 2 - 7 } & 1 & 2 & 1 & 2 & 1 & 2 \\
\hline $\mathrm{B}$ & $\ldots$ & $1,8 / 167$ & $\ldots$ & $2,7 / 250$ & $\ldots$ & $2,1 / 194$ \\
$\mathrm{Fe}$ & $10,0 / 179$ & $24,0 / 430$ & $18,0 / 323$ & $3,6 / 64,5$ & $8,0 / 143$ & $3,4 / 60,9$ \\
$\mathrm{Si}$ & $\ldots$ & $1,5 / 53,5$ & $\ldots$ & $1,4 / 49,8$ & $\ldots$ & $2,5 / 89,3$ \\
$\mathrm{Mn}$ & $6,8 / 123$ & $16,0 / 291$ & $14,0 / 254$ & $17,0 / 309$ & $1,7 / 30,9$ & $2,6 / 47,2$ \\
$\mathrm{Cu}$ & $0,62 / 9,8$ & $1,1 / 17,3$ & $0,90 / 14,2$ & $0,28 / 4,4$ & $0,14 / 2,2$ & $0,12 / 1,9$ \\
$\mathrm{Na}$ & $8,7 / 378$ & $8,8 / 382$ & $12,0 / 522$ & $2,3 / 100$ & $12,0 / 522$ & $6,7 / 291$ \\
$\mathrm{Zn}$ & $7,7 / 118$ & $13,0 / 199$ & $32,0 / 489$ & $31,0 / 474$ & $2,2 / 33,6$ & $2,3 / 35,2$ \\
\hline
\end{tabular}

Роль железа в процессах метаболизма очень велика и отражается на характере обмена остальных элементов. Этот металл в растительной клетке выполняет прежде всего каталитические функции. Ферменты, содержащие железо, участвуют в различных окислительно-восстановительных реакциях дыхания, азотного обмена (восстановление нитратов и нитритов в аммиак и др.) [32,33]. Видно, что количество железа является наибольшим в корке и снижается с продвижением вглубь ствола, причем отличия в его массовой доле невелики; так, содержание этого металла в корке выше, чем в лубе и в древесине, только в 1,5-2 раза.

Марганец присутствует в составе кофакторов у ряда ферментов, катализирующих различные звенья метаболических процессов. Этот элемент необходим для синтеза нуклеиновых кислот, он также способствует избирательному поглощению ионов из окружающей среды [32].

Цинк оказывает каталитическое действие на окислительно-восстановительные процессы (как восстановитель), влияет на ассимиляцию растениями азота и активизирует ферменты углеводного и липидного обмена [34]. Элемент не образует структурных соединений в живой клетке, а связан с энзимами, регулирующими клеточный обмен. Однако ряд исследователей указывают на связь цинка с клетчаткой, гемицеллюлозами и пектиновыми веществами клеточных оболочек [35]. Вследствие этого более высокое содержание этого элемента во флоэме вполне ожидаемо.

Распределение натрия по частям ствола является более равномерным, чем у вышеописанных элементов, причем его содержание несколько выше в ксилеме. Известно, что натрий относится к элементам, выполняющим электрохимическую [32] и осморегулирующую функции [36].

Медь - составная часть многих окислительно-восстановительных ферментов, в которых она образует прочный комплекс со специфическими белками. Медьсодержащие ферменты влияют на азотный обмен в растениях, на уровень синтеза фенолов и катализируют окисление полифенолов. Кроме того, ее присутствие необходимо для накопления органических форм фосфора, особенно сахарофосфатов и АТФ [32].

Содержание кремния, как и хрома, в ритидоме и флоэме примерно одинаково и меньше, чем в древесине в среднем в 2 раза. Способность кремния, поступившего в растение, активировать поглощение фосфора из почвы и удобрений [32] объясняет его повышенное содержание в древесине.

Принципиальное отличие бора от большинства микроэлементов состоит в том, что он поступает в растение в анионной форме и в последующих реакциях валентность не меняет [26]. Его участие в работе ферментативных систем связано со способностью к комплексообразованию с полигидроксильными соединениями. Бор принимает участие во многих физиологических и биохимических процессах: в регуляции роста, метаболизме фенолов, углеводов, нуклеиновых кислот, транспорте сахаров, дыхании, в процессах синтеза и лигнификации клеточных стенок [32,33].

Помимо приведенных в таблице 7 элементов, в образцах коры и древесины в малых количествах (менее 1 мг/100 г) обнаружены другие необходимые для живых организмов микроэлементы: кобальт, ванадий, молибден, хром. Все эти микроэлементы, благодаря переменной валентности и высокому окислительному потенциалу, так же, как железо и медь, прямо или косвенно участвуют в окислительновосстановительных реакциях [32].

Физиологическая роль других элементов (алюминия, бария, стронция), обнаруженных в коре и древесине в значительных количествах (более 5 мг/100 г), является мало изученной [24]. 


\section{Выводы}

1. Основными компонентами коры являются экстрактивные вещества, содержание которых превышает 50\%. В корке преобладающими компонентами являются вещества, извлекаемые водно-щелочным раствором (25\%), а в лубе - вещества, растворимые в водно-щелочном растворе (27\%) и этаноле (более $28 \%)$. Для наружной части коры характерно также высокое содержание лигнина $(22,5 \%)$.

2. Кора, в отличие от древесины, имеет повышенное содержание азот- и фосфорсодержащих соединений, большая часть которых находится во флоэме. Основная часть азота входит в состав структурных белков, а фосфора - в состав фосфолипидов и нуклеотидов.

3. Кора имеет высокое содержание макроэлементов (кальция, магния, калия), среди которых преобладает кальций, а также микроэлементов, которые принимают участие в окислительно-восстановительных реакциях, а именно железо, марганец, цинк и медь.

\section{Список литературь}

1. Zaks P.E. Chemystry of Bark // Wood and cellulose chemistry. Eds. by D.N.-S.Hon, N.Shiraisky. N.Y.; Basel. 1991. Pp. 253-330.

2. Азаров В.И., Буров А.В., Оболенская А.В. Химия древесины и синтетических полимеров. СПб., 1999, 628 с.

3. Алексеева Е.А. Изучение химического состава липидов коры осины и разработка технологии получения из них биоактивных веществ : дис. ... канд. техн. наук. Л., 1970. 163 с.

4. Фаустова Н.M. Химический состав коры и древесины осины Populus tremula L. : дис. ... канд. хим. наук. СПб., 2005, 173 с.

5. Лотова Л.И. Микроструктура коры основных лесообразующих лиственных деревьев и кустарников Восточной Европы. М., 1999. 114 с.

6. Смилга Я.Я. Осина. Рига, 1986. 238 с.

7. Некрасова В.Б. Лечебно-профилактические средства из биомассы дерева. СПб., 2006. 192 с.

8. Фаустова Н.М., Фаустова М.Е., Дейнеко И.П. Антибактериальная активность экстрактивных веществ коры осины в отношении некоторых пневмотропных микроорганизмов // Журнал микробиологии, эпидемиологии и иммунобиологии. 2006. №3, С. 3-7.

9. Талыкова М.Н. Фармакотехнологическое исследование коры осины : автореф. ... канд. фарм. наук. Барнаул, 1996. $25 \mathrm{c}$

10. Турецкова В.Ф., Лобанова И.Ю., Рассыпнова С.С., Талыкова М.Н. Осина обыкновенная как перспективный источник получения препаратов противоязвенного и противовоспалительного действия // Бюллетень сибирской медицины. 2011. №5. С. 105-111.

11. Выделение и анализ природных биологически активных веществ / ред. Е.Е. Сироткина. Томск. 1987. 185 с.

12. Плешков Б.П. Практикум по биохимии растений. М., 1976. 256 с.

13. Chalmers R. A. A Method for the Determination of Phosphorus in organic compounds // Anal. Chim. Acta. 1958. Vol. 18, N4-6. Pp. 575-577.

14. Жигунов А.В., Терешенкова И.А., Огиевский Д.В. Проведение биохимического анализа растительных образцов. Л., 1979. $43 \mathrm{c}$.

15. Оболенская А.В., Ельницкая 3.П., Леонович А.А. Лабораторные работы по химии древесины и целлюлозы. M., $1991.320 \mathrm{c}$.

16. Раскатов П.Б. Анатомия древесных растений. Воронеж, 1988. 80 с.

17. Гудвин Т., Мерсер Э. Введение в биохимию растений : пер. с англ.: в 2 т. М., 1986.

18. Стопский В.С., Ключкин В.В., Андреев Н.В. Химия жиров и продуктов переработки жирового сырья. М., 1992. $286 \mathrm{c}$.

19. Красильникова Л.А., Авксентьева О.А., Жмурко В.В., Садовниченко Ю.А. Биохимия растений. Ростов н/Д, 2004. $224 \mathrm{c}$.

20. Химия биологически активных природных соединений / под ред. Н.А. Преображенского и Р.П. Евстигнеевой. М., 1976. $456 \mathrm{c}$.

21. Шарова Е.И. Клеточная стенка растений. СПб., 2004. 156 с.

22. Степаненко Б.Н. Химия и биохимия углеводов (моносахариды). М., 1977. 204 с.

23. Ван Везер. Фосфор и его соединения. М., 1962. 687 с.

24. Рудакова Э.В., Каракис К.Д., Сидоршина Т.Н. и др. Микроэлементы: поступление, транспорт и физиологические функции в растениях. Киев, 1987. 184 с.

25. Кузнецов В.В., Дмитриева Г.А. Физиология растений. М., 2011. 783 с.

26. Крамер П. Д., Козловский Т.Т. Физиология древесных растений. М., 1983. 462 с.

27. Хьюз М. Неорганическая химия биологических процессов. М., 1983. 416 с.

28. Карпачевский Л.О. Лес и лесные почвы. М., 1981. 264 с.

29. Березина Н.А., Афанасьева Н.Б. Экология растений. М., 2001. 400 с.

30. Лир Х., Польстер Х., Фидлер Г.И. Физиология древесных растений. М., 1983. 423 с. 
31. Косиченко Н.Е. История анатомии древесины и коры. Воронеж, 2002. 76 с.

32. Ильин В.Б. Элементный химический состав растений. Новосибирск, 1985. 129 с.

33. Битюцкий Н.П. Необходимые микроэлементы растений. СПб., 2005. 256 с.

34. Бардинская М.С. Растительные клеточные стенки и их образование. Некоторые вопросы химии, биохимии и физиологии одревеснения. М., 1964. 160 с.

35. Физиология растительных организмов и роль металлов / ред. Н.М. Чернавской. М., 1988. 157 с.

36. Мусиенко Н.Н., Тернавский А.И. Корневое питание растений. Киев, 1989. 203 с.

Поступило в редакцию 9 сентября 2014 г.

После переработки 2 февраля 2015 г. 
Deineko I.P. ${ }^{{ }^{*}}$, Faustova N.M. ${ }^{2}$ ELEMENT AND GROUP CHEMICAL COMPOSITION OF ASPEN BARK AND

${ }^{1}$ Saint Petersburg State Technological University of Plant Polymers, Ivana Chernykh st., 4, St. Petersburg, 198095

(Russia), e-mail: ipdeineko@mail.ru

${ }^{2}$ Institute of Pharmacy of Saint-Petersburg, Partizanskaya ul., 27, St. Petersburg, 195248 (Russia),

e-mail: faustova-78@mail.ru

The results of the study elemental and group chemical composition of individual parts of the aspen bark (phloem, rhitidom) and wood are given. Bark, unlike wood, has a higher content of nutrients (N, P), micro- and macroelements, and also it is enriched with extractive substances, most of which (more than $45 \%$ ) is extracted with ethanol and $1 \% \mathrm{NaOH}$. The number of substances extracted from wood by solvents (slightly more than 5\%) is significantly lower than in the case of bark. However, in the alkaline solution wood passes a higher proportion of substances (about 15\%). The outer part of the bark compared to the phloem has a higher carbon content, but a lower content of nitrogen and especially phosphorus. Nitrogen-containing compounds in the bark are mainly represented by the structural components, and phosphorus-containing compounds - phospholipids and nucleotides. The concentration of macroelements in the phloem is about two times higher than in rhytidome and exceeds 50 $\mu \mathrm{mol} / \mathrm{g}$. In the largest amount the bark contains of magnesium, potassium and calcium, wherein the amount of the latter is more than half of the amount of inorganic elements. The main representatives of microelements $(1-5 \mu \mathrm{mol} / \mathrm{g})$ are zinc, iron, manganese, concentration of the others (boron, copper, cobalt, molybdenum, etc.) is very small (less than $1 \mu \mathrm{mol} / \mathrm{g}$ ). Cellulose content in the phloem and ritidome about the same or more than two times lower than in the wood.

Lignin maximally accumulated in the outer part of the bark, where the concentration is over $20 \%$. Wood is characterized by high content of acid-soluble lignin, the mass fraction exceeds $25 \%$ of the total content $(18 \%)$ of the biopolymer.

Keywords: aspen, bark, phloem, ritidom, wood, element composition, chemical composition, extractive substances, cellulose, lignin.

\section{References}

1. Zaks P.E. Chemystry of Bark // Wood and cellulose chemistry. Eds. by D.N.-S.Hon, N.Shiraisky. N.Y., Basel. 1991. Pp. 253-330.

2. Azarov V.I., Burov A.V., Obolenskaia A.V. Khimiia drevesiny $i$ sinteticheskikh polimerov. [Wood chemistry and synthetic polymers]. St. Petersburg, 1999, 628 p. (in Russ.).

3. Alekseeva E.A. Izuchenie khimicheskogo sostava lipidov kory osiny i razrabotka tekhnologii polucheniia iz nikh bioaktivnykh veshchestv : dis. ... kand. tekhn. nauk. [The study of the chemical composition of lipids aspen bark and development of technology for their bioactive substances: the dissertation Candidate of Technical Sciences]. Leningrad. 1970, 163 p. (in Russ.).

4. Faustova N.M. Khimicheskii sostav kory i drevesiny osiny Populus tremula L. : dis. ... kand. khim. nauk. [Faustova NM The chemical composition of the bark and wood of aspen Populus tremula L.: dissertation candidate of chemical sciences]. St. Petersburg, 2005, 173 p. (in Russ.).

5. Lotova L.I. Mikrostruktura kory osnovnykh lesoobrazuiushchikh listvennykh derev'ev $i$ kustarnikov Vostochnoi Evropy. [The microstructure of the main forest bark of deciduous trees and shrubs in Eastern Europe] Moscow, 1999, 114 p. (in Russ.).

6. Smilga Ia.Ia. Osina. [Aspen]. Riga, 1986, 238 p. (in Russ.).

7. Nekrasova V.B. Lechebno-profilakticheskie sredstva iz biomassy dereva. [Therapeutic and prophylactic agents of the biomass of a tree]. St. Petersburg, 2006. 192 p. (in Russ.).

8. Faustova N.M., Faustova M.E., Deineko I.P. Zhurnal mikrobiologii, epidemiologii i immunobiologii, 2006, no. 3, pp. 3-7. (in Russ.).

9. Talykova M.N. Farmakotekhnologicheskoe issledovanie kory osiny : avtoref. ... kand. farm. nauk. [Pharmaco technological research aspen bark: abstract Candidate of Pharmaceutical Sciences]. Barnaul. 1996, 25 p. (in Russ.).

10. Turetskova V.F., Lobanova I.Iu., Rassypnova S.S., Talykova M.N. Biulleten' sibirskoi meditsiny, 2011, no. 5, pp. 105-111. (in Russ.).

11. Vydelenie $i$ analiz prirodnykh biologicheski aktivnykh veshchestv. [Isolation and analysis of natural bioactive substances]. Ed. E.E. Sirotkina. Tomsk. 1987, 185 p. (in Russ.).

12. Pleshkov B.P. Praktikum po biokhimii rastenii. [Workshop on plant biochemistry]. Moscow, 1976, 256 p. (in Russ.).

13. Chalmers R.A. Anal. Chim. Acta., 1958, vol. 18, no. 4-6, pp. 575-577.

14. Zhigunov, A.V., Tereshenkova I.A., Ogievskii D.V. Provedenie biokhimicheskogo analiza rastitel'nykh obraztsov. [Biochemical analysis of plant samples]. Leningrad, 1979, 43 p. (in Russ.).

15. Obolenskaia A.V., El'nitskaia Z.P., Leonovich A.A. Laboratornye raboty po khimii drevesiny $i$ tselliulozy. [Laboratory work on the chemistry of wood and cellulose]. Moscow, 1991, 320 p. (in Russ.).

16. Raskatov P.B. Anatomiia drevesnykh rastenii. [Anatomy of woody plants]. Voronezh, 1988, 80 p. (in Russ.).

17. Gudvin T. Merser E. Vvedenie v biokhimiiu rastenii. [Introduction to plant biochemistry]. In 2 vol. Moscow, 1986. (in Russ.).

18. Stopskii V.S., Kliuchkin V.V., Andreev N.V. Khimiia zhirov i produktov pererabotki zhirovogo syr'ia. [Chemistry of fats and processed products of raw fat]. Moscow, 1992, 286 p. (in Russ.).

19. Krasil'nikova L.A., Avksent'eva O.A., Zhmurko V.V., Sadovnichenko Iu.A. Biokhimiia rastenii. [Phytochemistry.]. Rostov-on-Don, 2004, 224 p. (in Russ.).

\footnotetext{
* Corresponding author.
} 
20. Khimiia biologicheski aktivnykh prirodnykh soedinenii. [Chemistry of biologically active natural compounds]. Ed. N.A. Preobrazhenskii and R.P. Evstigneeva. Moscow, 1976, 456 p. (in Russ.).

21. Sharova E.I. Kletochnaia stenka rastenii. [The cell wall of plants]. St. Petersburg, 2004, 156 p. (in Russ.).

22. Stepanenko B.N. Khimiia i biokhimiia uglevodov (monosakharidy). [Chemistry and biochemistry of carbohydrates (monosaccharides)]. Moscow, 1977, 204 p. (in Russ.).

23. Van Vezer. Fosfor i ego soedineniia. [Phosphorus and its compounds]. Moscow, 1962, 687 p. (in Russ.).

24. Rudakova E.V., Karakis K.D., Sidorshina T.N. etc. Mikroelementy: postuplenie, transport i fiziologicheskie funktsii v rasteniiakh. [Trace elements: entry, transport and physiological function in plants]. Kiev, 1987, 184 p. (in Russ.).

25. Kuznetsov V.V., Dmitrieva G.A. Fiziologiia rastenii. [Vegetable physiology]. Moscow, 2011, 783 p. (in Russ.).

26. Kramer P. D., Kozlovskii T.T. Fiziologiia drevesnykh rastenii. [Physiology of woody plants]. Moscow, 1983 , 462 p. (in Russ.).

27. Kh'iuz M. Neorganicheskaia khimiia biologicheskikh protsessov. [Inorganic chemistry of biological processes]. Moscow, 1983, 416 p. (in Russ.).

28. Karpachevskii L.O. Les i lesnye pochvy. [Forest and forest soils]. Moscow, 1981, 264 p. (in Russ.).

29. Berezina N.A., Afanas'eva N.B. Ekologiia rastenii. [Plant ecology]. Moscow, 2001, 400 p. (in Russ.).

30. Lir Kh., Pol'ster Kh., Fidler G.I. Fiziologiia drevesnykh rastenii. [Physiology of woody plants]. Moscow, 1983, 423 p. (in Russ.).

31. Kosichenko N.E. Istoriia anatomii drevesiny $i$ kory. [The history of anatomy of wood and bark]. Voronezh, 2002, 76 p. (in Russ.).

32. Il'in V.B. Elementnyi khimicheskii sostav rastenii. [The elemental chemical composition of plants]. Novosibirsk, 1985, 129 p. (in Russ.).

33. Bitiutskii N.P. Neobkhodimye mikroelementy rastenii. [Necessary minerals plants]. St. Petersburg, 2005, 256 p. (in Russ.).

34. Bardinskaia M.S. Rastitel'nye kletochnye stenki i ikh obrazovanie. Nekotorye voprosy khimii, biokhimii i fiziologii odrevesneniia. [Plant cellular walls and their formation. Some questions of chemistry, biochemistry and physiology of lignification]. Moscow, 1964, 160 p. (in Russ.).

35. Fiziologiia rastitel'nykh organizmov i rol' metallov. [Physiology of plant organisms and the role of the metals]. Ed. N.M. Chernavskaia. Moscow, 1988, 157 p. (in Russ.).

36. Musienko N.N., Ternavskii A.I. Kornevoe pitanie rastenii. [The root power plants]. Kiev, 1989, 203 p. (in Russ.).

Received September 9, 2014

Revised February 2, 2015 